\title{
KOMPETISI ANTAR TERMINAL PETI KEMAS STUDI KASUS PELABUHAN TANJUNG PRIOK
}

\section{Terminal Container Competition in Port of Tanjung Priok}

Oleh:

\author{
Toufiq Al Amin ${ }^{1 *}$, Luky Adrianto ${ }^{2}$, Bagus Sartono ${ }^{3}$, Deni Achmad Soeboer ${ }^{4}$ \\ ${ }_{1}$ Sekretariat Jenderal, Kemenhub RI \\ ${ }^{2}$ Fakultas Perikanan dan Ilmu Kelautan, Institut Pertanian Bogor \\ ${ }^{3}$ Departemen Ilmu Matematika dan Statistik, Institut Pertanian Bogor \\ ${ }^{4}$ Staf Pengajar Program Studi Teknologi Perikanan Laut, Sekolah Pascasarjana Institut \\ Pertanian Bogor \\ "Korespondensi: tfqlamn@yahoo.com
}

\begin{abstract}
ABSTRAK
Artikel ini menginvestigasi kompetisi antar terminal peti kemas di Pelabuhan Tanjung Priok. Tujuan utama artikel ini adalah untuk dapat melihat kondisi persaingan antar terminal peti kemas dan perilaku terminal peti kemas dan perusahaan pelayaran dalam pengambilan keputusan penentuan terminal. Analisa empirik digunakan terhadap hasil survey kuisioner kepada perusahaan pelayaran berdasarkan faktor-faktor yang mempengaruhi penentuan pilihan penggunaan jasa terminal peti kemas. Pengujian ANOVA digunakan untuk menguji penilaian yang diberikan oleh responden, diasumsikan efisiensi waktu, kehandalan layanan, administrasi, operasional dan komersil merupakan kategori faktor-faktor yang membentuk penilaian performa terminal peti kemas, sedangkan perbandingan penilaian responden terhadap satu terminal peti kemas dengan terminal peti kemas yang lain dilakukan dengan pengujian Wilcoxon Signed Rank Test. Selanjutnya, analisa biaya digunakan untuk mendapatkan model dasar dari pemilihan terminal peti kemas oleh perusahaan pelayaran di Pelabuhan Tanjung Priok melalui pemodelan matematis yang terdiri dari 2 komponen utama, yaitu waktu pelayanan dan performa terminal/layanan tambahan terminal. Secara keseluruhan, artikel ini dapat membantu analisis lanjutan tentang peningkatan kemampuan terminal peti kemas dan memungkinkan terminal untuk mengetahui dan menyeimbangkan tingkat permintaan dan kapasitasnya sehingga dapat digunakan untuk menyusun strategi jangka panjang. Artikel ini juga dapat memberikan pengetahuan yang lebih baik terhadap kriteria perusahaan pelayaran saat memilih terminal peti kemas.
\end{abstract}

Kata kunci: Kompetisi antar terminal peti kemas, Pelabuhan Tanjung Priok, teori permainan non kooperatif, kapasitas terminal peti kemas, tarif terminal peti kemas.

\section{ABSTRACT}

This article investigates intra-port competition in Port of Tanjung Priok. The main purpose of this article is to be able to see the conditions of competition between container terminals and the behavior of container terminals and shipping companies in decision making terminal determination. Empirical analysis is used to the results of questionnaire surveys to shipping companies based on factors influencing the determination of the choice of container terminal services. ANOVA test is used to test the assessment given by the respondents, assuming that time efficiency, service reliability, administration, operational and commercial are categories of factors that form the performance assessment of the container terminal, while the comparison of one container terminal with another container terminal is done with Wilcoxon Signed Rank Test. Furthermore, cost analysis 
is used to derive the basic model of the selection of container terminals by shipping companies in Tanjung Priok Port through mathematical modeling consisting of 2 main components, service time and terminal performance / additional services terminal. Overall, this article can help with advanced analysis of upgrading container terminals and allowing the terminal to know and balance demand and capacity levels so that it can be used to develop long-term strategies. This article can also provide better knowledge of the criteria of shipping companies when selecting container terminals.

Keywords: Intra-port competition, port of Tanjung Priok, terminal container capacity, terminal container price.

\section{PENDAHULUAN}

Privatisasi pelabuhan telah menjadi trend kebijakan pada perdagangan internasional dalam upaya meningkatkan efisiensi pelabuhan, UNCTAD (2016) dalam penelitiannya mengatakan bahwa salah satu tujuan dari privatisasi pelabuhan adalah membuat pelabuhan atau terminal lebih efisien dan fleksibel. Ditetapkannya Undang-undang Nomor 17 Tahun 2008 tentang Pelayaran dimaksudkan memberikan peluang terhadap privatisasi pelabuhan dan penghapusan monopoli pengusahaan pelabuhan dengan pembentukan Badan Usaha Pelabuhan (BUP) sebagai pihak operator pelabuhan dan bukan lagi menjadi monopoli PT. Pelindo (persero). Menurut Setiono (2010), inovasi utama dari Undang-undang Pelayaran tersebut adalah pengembangan Otoritas Pelabuhan untuk mengawasi dan mengelola operasi dagang dalam setiap pelabuhan, badan usaha pelabuhan atau operator pelabuhan di sisi lain dapat berpartisipasi dalam menyediakan antara lain penganganan kargo, sarana penumpang, layanan tambat, pengisian bahan bakar, penyediaan air, penarikan kapal sekaligus penyimpanan dan lain sebagainya. Secara umum, PPIAF (2007) membedakan kompetisi yang berkaitan dengan pelabuhan menjadi 3 tipe, yaitu :

1. Inter-port competition (pelabuhan-pelabuhan dalam satu regional yang sama)

2. Intra-port competition (antar operator terminal dalam satu pelabuhan)

3. Intra-terminal competition (antar PBM dan penyedia jasa lainnya dalam satu terminal)

Dalam penelitian ini penulis fokuskan kepada kondisi persaingan yang kedua yaitu kompetisi antar operator terminal peti kemas dalam satu pelabuhan studi kasus Pelabuhan Tanjung Priok.

Kompetisi antar terminal peti kemas dapat terjadi dalam satu pelabuhan apabila dalam satu pelabuhan tersebut terdapat lebih dari satu terminal peti kemas dan masing-masing terminal di operasikan oleh operator terminal yang berbeda. Peningkatan kinerja operator terminal peti kemas dan perusahaan pelayaran sebagai dua bagian penting dalam biaya logistik berdampak sangat besar terhadap pengembangan ekonomi dan peningkatan kapasitas industri pelayaran maupun pelabuhan. Akan tetapi, setelah krisis ekonomi tahun 2008, dunia industri pelayaran mengalami penurunan yang sangat signifikan mengakibatkan terminal peti kemas dan perusahaan pelayaran menghadapi ketidakseimbangan supply dan demand dimana kapasitas kapal maupun terminal lebih besar dari permintaan pelayanan atau dengan kata lain terjadi kelebihan kapasitas (over capacity) yang selanjutnya menimbulkan konsekuensi tingginya persaingan di antara terminal peti kemas maupun antara perusahaan pelayaran.

Dalam kompetisi berbasis biaya logistik persaingan antara terminal dalam pelabuhan sangat jarang bersifat subtitusi sempurna bahkan dengan jenis dan tarif pelayanan yang relatif sama antar terminal peti kemas, dari persfektif pengguna pelabuhan/terminal peti kemas pemilihan terminal dapat tergantung dari efisiensi terminal, tingkat kedatangan kapal, tarif dari perusahaan pelayaran, dan lain-lain. Dalam kondisi kompetisi non tarif, perbedaan biaya dari performa terminal peti kemas ini merupakan salah satu faktor yang membedakan tingkat pemilihan terminal oleh pengguna jasa terminal dalam hal ini perusahaan pelayaran. Perusahaan pelayaran maupun pengguna jasa terminal lainnya akan memilih terminal peti kemas yang menawarkan biaya terendah dengan tingkat layanan 
yang diberikan. Secara teoritis, jika terminal peti kemas dapat menerapkan biaya rendah untuk jasa penggunaan terminal rendah, maka daya tarik terminal tersebut akan meningkat yang selanjutkan akan meningkatkan pangsa pasar dari terminal tersebut dibandingkan dengan terminal peti kemas lain yang menghasilkan biaya jasa pelayanan terminal yang lebih tinggi. Dengan kata lain biaya jasa yang dikeluarkan oleh pengguna jasa terminal peti kemas atas keseluruhan pelayanan atau real cost atas penggunaan terminal peti kemas dapat merefleksikan kondisi persaingan antar terminal peti kemas di Pelabuhan Tanjung Priok yang ditandai dengan penguasaan pangsa pasar oleh terminal peti kemas yang mampu menerapkan biaya rendah.

Penelitian pemilihan terminal dalam satu pelabuhan yang sama sering kali dalam salah satu tujuannya adalah untuk mengetahui faktor-faktor yang mempengaruhi keputusan pengguna jasa dalam memilih terminal peti kemas. Terdapat sedikitnya dua pihak penentu keputusan dari pemilihan pelabuhan/terminal, yaitu pemilik barang atau shipper/forwarder dan perusahaan pelayaran atau shipping line. Grosso dan Feliciana (2011), Manic (2013) menggunakan forwarder sebagai subjek penelitian, dimana Grosso dan Feliciana (2011) melakukan penelitian untuk mendapatkan faktor-faktor yang mempengaruhi forwarder dalam menentukan pelabuhan pilihan dengan menggunakan metode faktor analisis pada Pelabuhan Genoa dan Pelabuhan Antwerp. Sedangkan Manic (2013) menggunakan analisis DEA untuk mengetahui faktor dan kriteria yang paling mempengaruhi forwarder dalam menentukan pilihan pelabuhan.

\section{METODE PENELITIAN}

Pada penelitian ini pendekatan penelitian untuk evaluasi persaingan menggunakan model penelitian dari $\mathrm{Ng}$ (2006), alasan dari penggunaan model ini ialah karena model ini merupakan salah satu model penelitian yang menyajikan kerangka teoritis port competitiveness model (PCM) dimana dalam model penelitian tersebut dapat mengidentifikasi faktor utama yang mempengaruhi daya tarik pelabuhan, melihat perilaku pengguna jasa dalam memilih terminal, dan menginvestigasi kondisi persaingan pelabuhan. Kegiatan bisnis pelabuhan terutama dalam lingkungan yang kompetitif tidak hanya dituntut untuk efisien secara teknis akan tetapi juga efisien secara biaya. Talley (2007) memberikan contoh, efisiensi operasional pelabuhan secara teknis bertujuan untuk memaksimalkan jumlah peti kemas atau throughput yang dapat dilayani oleh kapasitas pelabuhan yang ada, dan efisiensi operasional pelabuhan secara biaya bertujuan untuk meminumkan biaya dalam penanganan peti kemas sesuai dengan jumlah throughput yang ada.

Dengan mengaplikasikan berbagai bentuk pemodelan dari unsur-unsur PCM, dapat disusun berbagai model matematis yang sesuai untuk menjelaskan aspek-aspek yang berbeda dari kompetisi dalam pelabuhan. Sehingga dalam penelitian ini, penulis juga menggunakan kalkulasi biaya keseluruhan (real cost) dan persamaan multinominal logit yang terdapat pada konsep PCM dan digunakan untuk membuat model matematis dari kompetisi antar empat terminal peti kemas pada Pelabuhan Tanjung Priok. Unsur terpenting dari PCM adalah konsep dari Port Attractivity atau daya tarik pelabuhan, dimana dapat diartikan sebagai potensi kemampuan pelabuhan tertentu dalam membuat pengguna jasa bersedia untuk membayar sejumlah biaya dari pelayanan yang diberikan. Seperti terlihat pada gambar 2. Di atas, terdapat tiga aspek utama pembentuk daya tarik pelabuhan, yaitu assesment process, values and perceptions, dan negotiations process and marketing (NPM).

Dalam penelitian kompetisi antar terminal peti kemas di Pelabuhan Tanjung Priok ini, penulis juga menggunakan konsep daya tarik terminal atau terminal attractivity (TA) sebagai kemampuan terminal peti kemas untuk menyakinkan pengguna jasa membayar biaya dari pelayanan yang diberikan. Untuk kebutuhan analisis values and perceptions, dan negotiations process and marketing (NPM) diklasifikasikan sebagai non assessment process dan tidak diperhitungkan dalam analisa generalize cost penggunaan terminal peti kemas oleh pengguna jasa, begitu juga dengan unsur port location atau lokasi pelabuhan juga tidak digunakan dalam analisa generalize cost dikarenakan 
penelitian ini hanya melihat kompetisi antar terminal peti kemas dalam satu pelabuhan (intra port competitions). Maka pada penelitian ini penulis hanya memasukkan faktor terminal sebagai aspek assessment process yang terdiri dari 3 faktor utama, yaitu:

1. Faktor Biaya, berupa berbagai macam tarif pelayanan penggunaan terminal seperti tarif bongkar muat, tarif tambatan, tarif penumpukan peti kemas, dan lain-lain.

2. Faktor Waktu, terdiri dari 2 variabel yaitu:

a. Waktu pelayanan, didefinisikan sebagai durasi pelayanan dalam satuan waktu (jam, hari, dan lain-lain) atas pelayanan terminal peti kemas

b. Efisiensi waktu pelayanan, didefinisikan sebagai tingkat penyelesaian waktu pelayanan atau waktu tunggu pelayanan terminal

3. Faktor kualitatif, terdiri dari 4 variabel yaitu:

a. Kehandalan dan ketepatan waktu pelayanan

b. Aspek Operasional

c. Aspek Komersial

d. Aspek Pemerintahan

Metode pengumpulan data survey penelitian ini menggunakan metode non-probability sampling yaitu penulis dalam hal ini menetapkan target responden, dikarenakan terminal peti kemas merupakan bisnis jasa pelayanan maka survey ditujukan kepada responden (personel perusahaan pelayaran) yang mempunyai kewenangan menentukan keputusan pemilihan terminal atau setidaknya responden yang mengetahui dan dapat memberikan masukan atau informasi kepada pengambil keputusan seperti personel marketing/kontrak dan personel operasional.

Kuisioner menggunakan format a likert-style yang terdiri dari pertanyaan tertutup atau closedended questions dan pertanyaan terbuka open-ended questions serta meminta responden untuk memberikan nilai kepada faktor-faktor yang mempengaruhi pemilihan terminal peti kemas. Berdasarkan beberapa studi terdahulu dalam pembuatan kuisioner, kuisioner dalam pada penelitian ini dibagi menjadi 3 bagian yaitu:

\section{Bagian A}

Pada bagian ini, responden diminta untuk mengisi informasi tentang responden dan perusahaan responden dan terminal yang dipilih saat ini.

\section{Bagian B}

Pada bagian ini, responden diminta menilai signifikansi faktor-faktor yang mempengaruhi daya tarik terminal dengan memberikan nilai pada skala signifikan dari 0 sampai dengan 5 .

\section{Bagian $\mathrm{C}$}

Untuk dapat membandingkan kualitas pelayanan dari masing-masing terminal peti kemas, pada bagian ini responden diminta untuk memberikan opini terhadap performa pelayanan masingmasing terminal dengan memberikan nilai apresiasi performa masing-masing terminal. Nilai skala apresiasi dan faktor-faktor performa terminal dari -3 sampai dengan +3 .

Saeed dan Larsen (2010) menyatakan dalam industri berbasis biaya logistik baik perusahaan pelayaran maupun pengguna jasa terminal lainnya akan memilih terminal peti kemas yang menawarkan biaya terendah dengan tingkat layanan yang diberikan, bahkan apabila berlaku satu tarif biaya handling charge untuk seluruh terminal peti kemas dalam satu pelabuhan yang sama, dari persfektif pengguna jasa terminal (terminal user) terdapat perbedaan biaya tambahan terutama biaya yang berkaitan dengan waktu pelayanan (biaya denda, biaya sewa kontainer, biaya bahan bakar). Maka dalam kompetisi non tarif, perbedaan biaya tambahan ini merupakan salah satu faktor yang 
membedakan tingkat pemilihan terminal atau market share dari masing-masing terminal peti kemas. Selain waktu pelayanan, faktor kualitatif (performa) dari terminal peti kemas atau jasa layanan lain yang dapat diberikan oleh terminal peti kemas kepada pengguna jasa merupakan faktor yang tidak dapat diabaikan dalam keputusan perusahaan pelayaran menentukan pilihan jasa terminal yang akan digunakan.

Diasumsikan dalam pemodelan matematis, biaya tambahan ini terdiri dari 2 komponen utama, yaitu waktu pelayanan dan performa terminal/layanan tambahan terminal. Secara umum fungsi real cost dari pengguna jasa yang menggunakan terminal peti kemas dirumuskan sebagai berikut: $\mathrm{Ng}$ (2006):

$$
C_{(t)}=M_{t}+\beta_{T} * T_{t}-\beta_{Q} * Q_{t}
$$

Dimana:

$C_{(t)}=$ Real Cost Pengguna Jasa pada Terminal i (US\$/TEUS)

$M_{t}=$ Biaya Tarif Pengguna Jasa pada Terminal i (US\$/TEUS)

$T_{i}=$ Waktu pelayanan pada Terminal i (TEUS/Jam)

$Q_{t}=$ Performa pelayanan Terminal i (indeks performa)

$\beta_{T}=$ Koefisien Biaya Waktu pelayanan (US\$/Jam)

$\beta_{Q}=$ Koefisien Biaya performa pelayanan (US\$/Indeks)

Variabel-variabel pada persamaan real cost di atas ditransformasikan ke dalam satu satuan unit yang sama (Rp/TEUS), sehingga variabel dalam persamaan di atas dapat diubah menjadi: $\mathrm{Ng}$ (2006)

$$
\begin{aligned}
& C_{(b)}=P C_{(b)}+D C_{(b)}-P T_{(b)} D / C \ldots \ldots \ldots \\
& D C_{(i)}\left[P C_{(i)}\right] * \frac{\left[A S S_{(D C)}\right]}{\left[A S S_{(P C)}\right]} \ldots \ldots \ldots \ldots \\
& P T_{(i)} D / C=T E_{(i)} D / C+Q F_{(i)} D
\end{aligned}
$$

Dimana:

$i=$ Terminal peti kemas JICT, KOJA, MAL, PTP

$C_{(i)}$

$=$ Real cost terminal $\mathrm{i}$

$P C_{(i)} \quad=$ Tarif terminal i (US\$/TEUS)

$D C_{(b)} \quad=$ Biaya waktu pelayanan terminal $\mathrm{i}(\mathrm{US} \$ / \mathrm{TEUS})$

$P T_{(t)} D / C=$ Penambahan/pengurangan biaya dari performa terminal i (US\$/TEUS)

$T E_{(b)} D / C=$ penambahan/pengurangan biaya dari efisiensi terminal i (US\$/TEUS)

$Q F_{(b)} D / C=$ penambahan/pengurangan biaya dari kualitatif terminal i (US\$/TEUS)

dimana untuk mendapatkan variabel-variabel nilai real cost tersebut dengan menggunakan data hasil survey kuisioner dilakukan langkah-langkah perhitungan sebagai berikut:

$$
T E_{(t)} D / C=\left[P C_{(t)}\right] * \frac{\left[A A S_{(T E, t)}\right]}{\left[A S S_{(P C)}\right]}
$$




$$
Q F_{(\ell)} D / C_{=}\left[P C_{(\ell)}\right] * \frac{\left[A A S_{(Q E, t)}\right]}{\left[A S S_{(P C)}\right]}
$$

Dimana:

$A S S_{(P C)}=$ Nilai rata-rata signifikansi tarif pelayanan terminal

$A A S_{(T E, t)}=$ Nilai rata-rata apresiasi efisiensi waktu pelayanan terminal $\mathrm{i}$

$A A S_{(Q F, b)}=$ Nilai rata-rata apresiasi faktor kualitatif pelayanan terminal $\mathrm{i}$

Hubungan antara utilitas dan daya tarik terminal adalah dengan mentransformasikan real cost yang dapat merefleksikan konsep utilitas melalui indeks komparasi real cost yang digambarkan dengan persamaan:

$$
U_{t}=\frac{1}{\frac{C_{i}}{C_{b}}}
$$

Maka, market share dari terminal peti kemas i, dapat di rumuskan dalam persamaan logit sebagai berikut:

$$
E_{t}=\frac{U_{i}}{\sum_{f} U_{t}}, i=\text { Terminal peti kemas JICT, KOJA, MAL }
$$

Dimana:

$E_{t}=$ Estimasi Market Share terminal i

$U_{\ell}=$ Utilitas terminal i

\section{HASIL DAN PEMBAHASAN}

\section{Studi Kasus}

Pelabuhan Tanjung Priok merupakan pelabuhan terbesar dan tersibuk dalam melayani lebih dari dua per tiga perdagangan internasional Indonesia, berfungsi sebagai pintu gerbang utama berlangsungnya kegiatan ekspor maupun impor barang. Kebijakan Pelabuhan Tanjung Priok dalam pengoperasian dermaga adalah menggandeng pihak ketiga atau perusahaan mitra (terminal operator/TO) untuk ikut mengelola beberapa dermaga, yaitu:

1. PT. Jakarta International Container Terminal (JICT)

2. KSO Terminal Peti kemas Koja (TPK Koja)

3. PT. Pelabuhan Tanjung Priok (PTP), yang mengoperasikan terminal III

4. PT. Mustika Alam Lestari (MAL), yang mengoperasikan terminal PT. MTI

Berikut jumlah kargo peti kemas yang ditangani oleh Pelabuhan Tanjung Priok dan pangsa pasar dari 4 terminal peti kemas terlihat dari Tabel 1 yang menggambarkan arus peti kemas internasional dari tahun 2011 sampai dengan 2015.

Tabel 1 Keterangan kapal

\begin{tabular}{cccccc}
\hline Terminal & 2011 & 2012 & 2013 & 2014 & 2015 \\
\hline JICT & 2.224 .882 & 2.346 .894 & 2.424 .232 & 2.355 .906 & 2.223 .176 \\
TPK KOJA & 824.951 & 820.730 & 851.885 & 872.508 & 975.438 \\
MAL & 409.283 & 445.494 & 402.890 & 339.171 & 298.205 \\
PTP & 228.591 & 201.295 & 105.564 & 66.819 & 17.728 \\
\hline Total & 3.687 .707 & 3.814 .413 & 3.784 .571 & 3.634 .404 & 3.514 .547 \\
\hline \multicolumn{5}{c}{ Sumber: Otoritas Pelabuhan Tanjung Priok (olahan) }
\end{tabular}

Sumber: Otoritas Pelabuhan Tanjung Priok (olahan) 


\section{Penilaian perusahaan pelayaran terhadap performa terminal peti kemas}

Berdasarkan informasi yang didapat dari kuisioner Bagian A, Tabel 2 menggambarkan pilihan terminal-terminal peti kemas oleh responden atau perusahaan pelayaran.

Tabel 2. pilihan terminal peti kemas di Pelabuhan Tanjung Priok oleh perusahaan pelayaran berdasarkan kuisioner

\begin{tabular}{ccccc}
\hline Jumlah Perusahaan & JICT & KOJA & MAL & PTP \\
\hline 23 Perusahaan Pelayaran & 19 & 16 & 7 & 12 \\
\hline
\end{tabular}

Tabel 3. nilai rata-rata signifikasi yang mempengaruhi pemilihan terminal

\begin{tabular}{lc}
\hline \multicolumn{1}{c}{ Faktor } & ASS (average significance score) \\
\hline Faktor harga & 3,57 \\
\hline Tarif & \\
Faktor waktu & 3,61 \\
\hline Waktu bongkar muat & 3,43 \\
efisiensi terminal & \\
Faktor performa & \\
kehandalan layanan & 3,26 \\
antrian/tundaan kapal & 3,22 \\
tingkat kecelakaan & \\
Administrasi & 3,35 \\
kebijakan, aturan, prosedur & \\
Operasional & 3,43 \\
Jalan akses & 3,52 \\
kualitas sarana terminal & 3,57 \\
kualitas prasarana terminal & 3,57 \\
layanan IT & 3,22 \\
ketersediaan layanan pendukung & 3,17 \\
Komersial & 3,35 \\
personel professional & 3,22 \\
permintaan khusus dari pemilik barang & \\
kontak personal & 3,17 \\
promosi dari terminal & \\
reputasi terminal & \\
kecepatan respon aduan & \\
\hline & \\
\hline
\end{tabular}

Pada Bagian B kuisioner yang diberikan kepada responden, responden diminta untuk memberikan penilaian terhadap berbagai faktor yang mempengaruhi daya tarik pemilihan terminal peti kemas, Tabel 3 memberikan hasil dari nilai rata-rata signifikansi dari faktor-faktor tersebut. Bagian C kuisioner meminta responden untuk memberikan penilaian terhadap performa dari masingmasing terminal peti kemas di Pelabuhan Tanjung Priok, Tabel 4 memperlihatkan nilai rata-rata apresiasi responden terhadap layanan dan performa terminal peti kemas di Pelabuhan Tanjung Priok. 
Tabel 4. Nilai rata-rata apresiasi terminal peti kemas di Pelabuhan Tanjung Priok

\begin{tabular}{lcccc}
\hline \multicolumn{1}{c}{ FAKTOR } & \multicolumn{4}{c}{ AAS (average appreciation score) } \\
& KOJA & JICT & MAL & PTP \\
\hline $\begin{array}{l}\text { Time efisiensi } \\
\quad \begin{array}{l}\text { ffisiensi terminal } \\
\text { kehandalan layanan }\end{array}\end{array}$ & 2 & 1,84 & 0,86 & 1,67 \\
$\quad$ antrian/tundaan kapal & 1,88 & 1,84 & 1,71 & 2 \\
$\quad \begin{array}{l}\text { tingkat kecelakaan } \\
\text { Administrasi }\end{array}$ & 1,38 & 1,42 & 1,71 & 1,42 \\
$\quad$ kebijakan, aturan, prosedur & 1,75 & 1,79 & 1,71 & 1,25 \\
Operasional & & & & \\
Jalan akses & 1,75 & 1,58 & 2,14 & 1,75 \\
$\quad$ kualitas sarana terminal & 1,94 & 1,89 & 1,86 & 2,08 \\
$\quad$ kualitas prasarana terminal & 2,06 & 2,11 & 0,86 & 1,50 \\
$\quad$ layanan IT & 1,88 & 1,84 & 2 & 1,92 \\
$\quad$ ketersediaan layanan & 1,81 & 1,89 & 1 & 1,25 \\
$\quad$ pendukung & & & & \\
Komersial & & & & \\
$\quad$ personel professional & 1,94 & 2 & 1,86 & 1,75 \\
$\quad$ kontak personal \\
$\begin{array}{l}\text { promosi dari terminal } \\
\text { reputasi terminal }\end{array}$ & 1,94 & 2 & 1,86 & 1,83 \\
$\quad$ kecepatan respon aduan & 1,88 & 1,89 & 1,86 & 1,92 \\
\hline
\end{tabular}

\section{Gambaran umum penilaian performa terminal peti kemas}

Secara sekilas dari hasil survei kuisioner pada Tabel 4. terlihat perbedaan dari opini responden dalam menilai empat terminal peti kemas yang ada di Pelabuhan Tanjung Priok, akan tetapi untuk mendapatkan kesimpulan yang objektif diperlukan pengujian statistik. Pengujian ANOVA digunakan untuk menguji penilaian yang diberikan oleh responden, diasumsikan efisiensi waktu, kehandalan layanan, administrasi, operasional dan komersil merupakan kategori faktor-faktor yang membentuk penilaian performa terminal peti kemas. Hipotesis nol adalah jika F-value lebih kecil dari nilai kritis yang berarti tidak terdapat perbedaan yang signifikan dalam penilaian responden terhadap empat terminal peti kemas dan jika nilai F-value lebih besar dari nilai kritis, maka terdapat perbedaan yang signifikan dalam penilaian responden terhadap empat terminal peti kemas atau hipotesis nol ditolak. Berikut hasil perhitungan nilai F-value dapat dilihat pada Tabel 5.

Hasil pada Tabel 5. mengindikasikan bahwa pada seluruh kategori responden memberikan penilaian perbedaan performa yang tidak cukup signifikan diantara terminal peti kemas atau dengan kata lain responden menilai performa dari ke empat terminal peti kemas di Pelabuhan Tanjung Priok tidak signifikan perbedaannya. Akan tetapi pengujian ANOVA hanya dapat menjelaskan signifikansi perbedaan penilaian responden terhadap seluruh terminal peti kemas, sedangkan perbedaan penilaian diantara masing-masing terminal peti kemas tidak dapat diketahui. Perbandingan penilaian responden terhadap satu terminal peti kemas dengan terminal peti kemas yang lain dapat dilakukan dengan pengujian Wilcoxon Signed Rank Test. Dasar pengambilan keputusan untuk menerima atau menolak Ho pada uji wilcoxon signed rank test adalah sebagai berikut: Jika probabilitas (Asymp.Sig) $<0,05$ maka Ho ditolak dan Ha diterima. Jika probabilitas (Asymp.Sig) $>0,05$ maka Ho diterima dan Ho ditolak. Seperti pengujian ANOVA, efisiensi waktu, kehandalan layanan, administrasi, operasional dan komersil merupakan kategori faktor-faktor yang membentuk penilaian performa terminal peti 
kemas. Hasil pengujian Wilcoxon signed rank test terhadap masing-masing kategori seperti terlihat pada Tabel 6, Tabel 7, Tabel 8, Tabel 9 dan Tabel 10 memperlihatkan nilai Asymp.Sig pada keempat terminal peti kemas yang diuji memiliki nilai lebih besar dari 0,05 (Asymp.Sig > 0,05) maka Ho diterima yaitu tidak terdapat perbedaan yang cukup signifikan antara keempat terminal peti kemas.

Tabel 5. Nilai F-value

\begin{tabular}{l|c}
\hline Kategori & F-Value \\
\hline Efisiensi Waktu & $\left.1,95^{*}\right)$ \\
Kehandalan Layanan & $\left.0,08^{*}\right)$ \\
Administrasi & $\left.2,65^{*}\right)$ \\
Operasional & $\left.1,08^{*}\right)$ \\
Komersional & $\left.1,79^{*}\right)$ \\
\hline \multicolumn{2}{c|}{ Cat: nilai critical value (F-crit) adalah 2,79 dengan signifikansi level 0,05 } \\
${ }^{*}$ ) nilai F- value < dari nilai F-crit (tidak signifikan perbedaannya)
\end{tabular}

Tabel 6. Matrik pengujian Wilcoxon signed rank test kategori faktor efisiensi waktu

\begin{tabular}{lcccc}
\hline Terminal & KOJA & JICT & MAL & PTP \\
\hline KOJA & & 0,414 & 0,267 & 0,157 \\
JICT & 0,414 & & 0,131 & 0,157 \\
MAL & 0,267 & 0,131 & & 0,655 \\
PTP & 0,157 & 0,157 & 0,655 & \\
\hline \multicolumn{5}{l}{ Cat: nilai signifikansi level 0,05 }
\end{tabular}

Tabel 8. Matrik pengujian Wilcoxon signed rank test kategori faktor administrasi

\begin{tabular}{lcccc}
\hline Terminal & KOJA & JICT & MAL & PTP \\
\hline KOJA & & 1,000 & 0,317 & 0,276 \\
JICT & 1,000 & & 0,317 & 0,194 \\
MAL & 0,317 & 0,317 & & 0,102 \\
PTP & 0,276 & 0,194 & 0,102 & \\
\hline \multicolumn{5}{c}{ Cat: nilai signifikansi level 0,05 }
\end{tabular}

Tabel 7. Matrik pengujian Wilcoxon signed rank test kategori faktor kehandalan layanan

\begin{tabular}{lcccc}
\hline Terminal & KOJA & JICT & MAL & PTP \\
\hline KOJA & & 0,577 & 0,317 & 0,157 \\
JICT & 0,577 & & 1,000 & 0,414 \\
MAL & 0,317 & 1,000 & & 0,317 \\
PTP & 0,157 & 0,414 & 0,317 & \\
\hline \multicolumn{5}{l}{ Cat: nilai signifikansi level 0,05 }
\end{tabular}

Tabel 9. Matrik pengujian Wilcoxon signed rank test kategori faktor operasional

\begin{tabular}{lcccc}
\hline Terminal & KOJA & JICT & MAL & PTP \\
\hline KOJA & & 0,655 & 0,102 & 0,083 \\
JICT & 0,655 & & 0,276 & 0,336 \\
MAL & 0,102 & 0,276 & & 0,157 \\
PTP & 0,083 & 0,336 & 0,157 & \\
\hline \multicolumn{5}{l}{ Cat: nilai signifikansi level 0,05}
\end{tabular}

Tabel 10. Matrik pengujian T-test kategori faktor komersil

\begin{tabular}{lcccc}
\hline Terminal & KOJA & JICT & MAL & PTP \\
\hline KOJA & & 0,102 & 0,317 & 0,276 \\
JICT & 0,102 & & 0,317 & 0,194 \\
MAL & 0,317 & 0,317 & & 0,450 \\
PTP & 0,276 & 0,194 & 0,450 & \\
\hline \multicolumn{5}{l}{ Cat: nilai signifikansi level 0,05 }
\end{tabular}

\section{Analisa biaya}

Menggunakan nilai AAS dan ASS hasil kuisioner dihitung nilai real cost yang dikeluarkan oleh pengguna jasa. Tabel 11 memperlihatkan nilai real cost pada empat terminal peti kemas pada Pelabuhan Tanjung Priok sedangkan Tabel 12. Memperlihatkan perbandingan hasil perhitungan estimasi pangsa pasar dengan real pangsa pasar. 
Tabel 11. Biaya keseluruhan penggunaan jasa pelayanan terminal peti kemas di Pelabuhan Tanjung Priok (dalam satuan US\$/TEUS)

\begin{tabular}{ccccccc}
\hline Terminal & $\begin{array}{c}\text { Tarifjasa } \\
\text { layanan } \\
\text { bongkar } \\
\text { muat }\end{array}$ & $\begin{array}{c}\text { Biaya waktu } \\
\text { pelayanan } \\
\text { bongkar } \\
\text { muat }\end{array}$ & $\begin{array}{c}\text { Penambahan/ } \\
\text { pengurangan } \\
\text { efisiensi waktu }\end{array}$ & $\begin{array}{c}\text { Penambahan/ } \\
\text { pengurangan } \\
\text { faktor } \\
\text { kualitatif }\end{array}$ & $\begin{array}{c}\text { Penambahan/ } \\
\text { pengurangan } \\
\text { performa } \\
\text { terminal }\end{array}$ & Real cost \\
\hline$(1)$ & $(2)$ & $(3)$ & $(4)$ & $(5)$ & $(6)=(4)+(5)$ & $(6)=$ \\
KOJA & 95 & 96,16 & 53,29 & 49,30 & 102,59 & 88,57 \\
JICT & 95 & 96,16 & 49,09 & 49,83 & 98,91 & 92,24 \\
$M A L$ & 95 & 96,16 & 22,84 & 45,57 & 68,40 & 122,75 \\
$P T P$ & 95 & 96,16 & 44,41 & 45,03 & 89,44 & 101,72 \\
\hline
\end{tabular}

Tabel 12. Perbandingan estimasi dan real pangsa pasar

\begin{tabular}{c|ccc}
\hline Terminal & $\begin{array}{c}\text { Jumlah bongkar muat 2015 } \\
(\text { TEU })^{*}\end{array}$ & $\begin{array}{c}\text { Pangsa pasar 2015 } \\
\text { (\%) }\end{array}$ & $\begin{array}{c}\text { Estimasi Pangsa Pasar } \\
\text { (\%) }\end{array}$ \\
\hline KOJA & 975,438 & 28 & 28 \\
JICT & $2.223,176$ & 63 & 27 \\
MAL & 298,205 & 8 & 21 \\
PTP & 17,728 & 1 & 24 \\
\hline
\end{tabular}

*) Sumber: Otoritas Pelabuhan Tanjung Priok (olahan)

\section{KESIMPULAN DAN SARAN}

\section{Kesimpulan}

Penggunaan model diagram Port Competition Model (PCM) dengan studi kasus persaingan antar terminal peti kemas di Pelabuhan Tanjung Priok pada penelitian ini menghasilkan gambaran akan bagaimana persaingan diantara terminal peti kemas di Pelabuhan Tanjung Priok sebagai berikut:

a. Penilaian terhadap signifikasi faktor yang dapat mempengaruhi daya tarik terminal dalam persaingan antar terminal peti kemas di Pelabuhan Tanjung Priok oleh perusahaan pelayaran mengindikasikan bahwa tarif terminal dan waktu bongkar muat merupakan faktor terpenting dinilai oleh perusahaan pelayaran dalam pemilihan terminal.

b. Hasil pengujian ANOVA terhadap signifikansi perbedaan lima faktor penilaian performa terminal yaitu faktor efisiensi waktu bongkar muat, faktor kehandalan layanan, faktor administrasi, faktor operasional dan faktor komersil menghasilkan nilai $\mathrm{F}$-value $<\mathrm{F}$-crit. Sejalan dengan hasil pengujian ANOVA, pengujian Wilcoxon sign rank test yang menguji signifikansi perbedaan performa diantara keempat terminal peti kemas menghasilkan nilai Asymp.Sig > 0,05. Maka dapat disimpulkan bahwa tidak terdapat perbedaan yang signifikan dari performa pelayanan yang ditawarkan oleh keempat terminal peti kemas di Pelabuhan Tanjung Priok.

c. Nilai perhitungan estimasi pangsa pasar keempat terminal peti kemas dengan hasil, $28 \%$ pangsa pasar terminal KOJA, 27\% pangsa pasar terminal JICT, 21\% pangsa pasar terminal MAL, dan 24\% pangsa pasar terminal PTP memiliki perbedaan yang cukup signifikan dari nilai real pangsa pasar keempat terminal peti kemas. kondisi ini membuktikan bahwa pemilihan terminal peti kemas oleh perusahaan pelayaran bukan lebih kepada persaingan ketersediaan kapasitas dan harga dibandingkan dengan persaingan performa pelayanan. 
Saran

Di luar komponen permintaan, kapasitas, dan tarif terminal peti kemas yang diperhitungkan dalam penelitian ini, untuk kebutuhan penelitian selanjutnya dapat dimasukkan beberapa parameter penting lainnya seperti kebijakan pemerintah, karakteristik hinterland, nilai dan persepsi pengguna jasa, marketing proses dan parameter lain yang diperlukan. Variasi kondisi asimestris perusahaan pelayaran maupun kondisi asimetris terminal peti kemas juga diperlukan guna mendapatkan pemahaman perilaku pengguna jasa terminal peti kemas yang lebih akurat.

\section{DAFTAR PUSTAKA}

Ng AKY. 2006. Theory and Structure of Port Competition: Case Study of Container Transhipment in North Europe [dissertation]. Oxford (UK): University of Oxford.

[PPIAF] Public-Private Insfrastructure Advisory Facility. 2007. Port Reform Tool Kit, Modules 1-8. 2nd edition. Washington DC. World Bank.

Saeed N. \& Larsen OL. 2010. An application of cooperative game among container terminals of one port. European Journal of Operational Research. 203(2): 392-403.

Setiono BA. 2010. Analisis Faktor-Faktor yang Mempengaruhi Kinerja Pelabuhan. Jurnal Aplikasi Pelayaran dan Kepelabuhanan. 1(1): 39-60.

Talley WK. 2007. Port Performance: An Economics Perspective. Research in Transportation Economics. 17: 499-516

[UNCTAD] United Nation Conference on Trade and Development. 2016. Linking Performance Indicators to Strategic Objectives. New York (US): United Nation.

[Kemenhub RI] Kementerian Perhubungan Republik Indonesia. 2008. Undang-Undang Nomor 17 Tahun 2008 tentang pelayaran. Jakarta (ID): Kemenhub RI.

Grosso M. \& Feliciana M. 2011. Criteria of Container Port Choice: Fokus on the Mediteranean. Association for European Transport and contributors. 4(I): 139-160.

Manic B. 2013. Benchmarking Analysis of Port Services from a Perspective of Freight Forwarders [dissertation]. London (UK): City University London. 
Lampiran 1a. Hasil Analisa ANOVA dan Wilcoxon Signed Rank Test Faktor Efisiensi Waktu

\begin{tabular}{|c|c|c|c|c|c|c|}
\hline $\begin{array}{l}\text { Source of } \\
\text { Variation }\end{array}$ & $S S$ & $d f$ & $M S$ & $F$ & $P$-value & F crit \\
\hline Between Groups & 6,783208 & 3 & 2,261069 & 1,947515 & 0,133935 & 2,790008 \\
\hline Within Groups & 58,050125 & 50 & 1,161003 & & & \\
\hline Total & 64,833333 & 53 & & & & \\
\hline
\end{tabular}

NPar Tests

[Efisiensi Waktu]

Wilcoxon Signed Ranks Test

\begin{tabular}{lr|r|r|r|r|r} 
& \multicolumn{7}{c}{ Test Statistics $^{\mathrm{a}}$} & & \\
& JICT - KOJA & MAL - KOJA & PTP - KOJA & MAL - JICT & PTP - JICT & PTP - MAL \\
\hline Z &,$- 816^{\mathrm{b}}$ & $-1,089^{\mathrm{b}}$ & $-1,414^{\mathrm{b}}$ & $-1,512^{\mathrm{b}}$ & $-1,414^{\mathrm{b}}$ &,$- 447^{\mathrm{c}}$ \\
\hline $\begin{array}{l}\text { Asymp. Sig. } \\
\text { (2-tailed) }\end{array}$ &, 414 &, 276 &, 157 &, 131 &, 157 &, 655 \\
\hline
\end{tabular}

a. Wilcoxon Signed Ranks Test

b. Based on positive ranks.

c. Based on negative ranks.

Lampiran 1b. Hasil Analisa ANOVA dan Wilcoxon Signed Rank Test Faktor Kehandalan Layanan

\begin{tabular}{|c|c|c|c|c|c|c|}
\hline $\begin{array}{l}\text { Source of } \\
\text { Variation }\end{array}$ & $S S$ & $d f$ & $M S$ & $F$ & $P$-value & $F_{\text {crit }}$ \\
\hline Between Groups & 0,083246 & 3 & 0,027749 & 0,075697 & 0,972807 & 2,790008 \\
\hline Within Groups & 18,32879 & 50 & 0,366576 & & & \\
\hline Total & 18,41204 & 53 & & & & \\
\hline
\end{tabular}

\section{NPar Tests}

[Kehandalan Layanan]

Wilcoxon Signed Ranks Test

Test Statistics ${ }^{\mathrm{a}}$

\begin{tabular}{lr|r|r|r|r|r} 
& JICT - KOJA & MAL - KOJA & PTP - KOJA & MAL - JICT & PTP - JICT & PTP - MAL \\
\hline Z &,$- 557^{\mathrm{b}}$ & $-1,000^{\mathrm{c}}$ & $-1,414^{\mathrm{c}}$ &, $000^{\mathrm{d}}$ &,$- 816^{\mathrm{c}}$ & $-1,000^{\mathrm{c}}$ \\
\hline $\begin{array}{l}\text { Asymp. Sig. } \\
\text { (2-tailed) }\end{array}$ &, 577 &, 317 &, 157 & 1,000 &, 414 &, 317 \\
\hline
\end{tabular}
a. Wilcoxon Signed Ranks Test
b. Based on positive ranks.
c. Based on negative ranks.
d. The sum of negative ranks equals the sum of positive ranks. 
Lampiran 1c. Hasil Analisa ANOVA dan Wilcoxon Signed Rank Test Faktor Administrasi

\begin{tabular}{|c|c|c|c|c|c|c|}
\hline $\begin{array}{c}\text { Source of } \\
\text { Variation }\end{array}$ & $S S$ & $d f$ & $M S$ & $F$ & $P$-value & F crit \\
\hline Between Groups & 3,188301 & 3 & 1,062767 & 2,647524 & 0,059024 & 2,790008 \\
\hline Within Groups & 20,07096 & 50 & 0,401419 & & & \\
\hline Total & 23,25926 & 53 & & & & \\
\hline
\end{tabular}

NPar Tests

[Administrasi]

Wilcoxon Signed Ranks Test

\begin{tabular}{lr|r|r|r|r|r} 
& \multicolumn{9}{c}{ Test Statistics $^{\mathrm{a}}$} & & \\
& JICT - KOJA & MAL - KOJA & PTP - KOJA & MAL - JICT & PTP - JICT & PTP - MAL \\
\hline Z &, $000^{\mathrm{b}}$ & $-1,000^{\mathrm{c}}$ & $-1,089^{\mathrm{d}}$ & $-1,000^{\mathrm{c}}$ & $-1,300^{\mathrm{d}}$ & $-1,633^{\mathrm{d}}$ \\
\hline $\begin{array}{l}\text { Asymp. Sig. } \\
\text { (2-tailed) }\end{array}$ & 1,000 &, 317 &, 276 &, 317 &, 194 &, 102 \\
\hline
\end{tabular}

a. Wilcoxon Signed Ranks Test

b. The sum of negative ranks equals the sum of positive ranks.

c. Based on negative ranks.

d. Based on positive ranks.

Lampiran 1d. Hasil Analisa ANOVA dan Wilcoxon Signed Rank Test Faktor Operasional

\begin{tabular}{|c|c|c|c|c|c|c|}
\hline $\begin{array}{c}\text { Source of } \\
\text { Variation }\end{array}$ & $S S$ & $d f$ & $M S$ & $F$ & $P$-value & $F$ crit \\
\hline Between Groups & 0,683263 & 3 & 0,227754 & 1,078791 & 0,366604 & 2,790008 \\
\hline Within Groups & 10,556 & 50 & 0,21112 & & & \\
\hline Total & 11,23926 & 53 & & & & \\
\hline
\end{tabular}

\section{NPar Tests}

[Operasional]

Wilcoxon Signed Ranks Test

\begin{tabular}{lr|r|r|r|r|r|r} 
& \multicolumn{9}{c}{ Test Statistics $^{\mathbf{a}}$} & & \\
& JICT - KOJA & & MAL - KOJA & PTP - KOJA & MAL - JICT & PTP - JICT & PTP - MAL \\
\hline Z &,$- 447^{\mathrm{b}}$ & $-1,633^{\mathrm{c}}$ & $-1,732^{\mathrm{c}}$ & $-1,089^{\mathrm{c}}$ &,$- 962^{\mathrm{c}}$ & $-1,414^{\mathrm{c}}$ \\
\hline $\begin{array}{l}\text { Asymp. Sig. } \\
\text { (2-tailed) }\end{array}$ &, 655 &, 102 &, 083 &, 276 &, 336 &, 157 \\
\hline
\end{tabular}
a. Wilcoxon Signed Ranks Test
b. Based on negative ranks.
c. Based on positive ranks. 
Lampiran 1e. Hasil Analisa ANOVA dan Wilcoxon Signed Rank Test Faktor Komersial

\begin{tabular}{lcrcccc} 
ANOVA & \multicolumn{1}{c}{ Source of } \\
$\quad$ Variation & \multicolumn{1}{c}{$S$ S } & \multicolumn{1}{c}{ df } & \multicolumn{1}{c}{ MS } & \multicolumn{1}{c}{$F$} & $P$-value & F crit \\
\hline Between Groups & 0,346371 & 3 & 0,115457 & 1,785662 & 0,161895 & 2,790008 \\
Within Groups & 3,232888 & 50 & 0,064658 & & & \\
\hline Total & 3,579259 & 53 & & & & \\
\hline
\end{tabular}

NPar Tests

[Komersial]

Wilcoxon Signed Ranks Test

\begin{tabular}{|c|c|c|c|c|c|c|}
\hline \multicolumn{7}{|c|}{ Test Statistics ${ }^{\mathrm{a}}$} \\
\hline & JICT - KOJA & $\begin{array}{l}\text { MAL - } \\
\text { KOJA }\end{array}$ & $\begin{array}{l}\text { PTP - } \\
\text { KOJA }\end{array}$ & MAL - JICT & PTP - JICT & PTP - MAL \\
\hline $\mathrm{Z}$ & $-1,633^{b}$ & $-1,000^{c}$ & $-1,089^{c}$ & $-1,000^{c}$ & $-1,300^{c}$ &,$- 756^{\mathrm{c}}$ \\
\hline $\begin{array}{l}\text { Asymp. Sig } \\
\text { (2-tailed) }\end{array}$ & ,102 & 317 & ,276 & 317 & ,194 &, 450 \\
\hline
\end{tabular}

a. Wilcoxon Signed Ranks Test

b. Based on negative ranks.

c. Based on positive ranks. 